\title{
DAMPAK MAKROEKONOMI TERHADAP NONPERFORMING LOANS: STUDI KASUS BANK KONVENSIONAL DI ASEAN
}

\author{
Alvin Sugeng Prasetyo \\ Universitas Trunojoyo Madura \\ alvin.prasetyo@trunojoyo.ac.id
}

\begin{abstract}
ABSTRAK
Studi ini bertujuan untuk menguji dan menganalisis dampak variabelvariabel makroekonomi terhadap Nonperforming Loans (NPL) Bank Konvensional di ASEAN. Metode yang digunakan yaitu panel dinamis selama periode 2005-2018. Hasil estimasi menunjukkan bahwa variabel makroekonomi seperti pertumbuhan ekonomi, suku bunga kredit, inflasi, dan pengangguran berpengaruh signifikan terhadap Nonperforming Loans (NPL) Bank Konvensional di ASEAN. Keterbatasan dalam studi ini yaitu tidak menggunakan variabel indikator perbankan sebagai penentu NPL dan terbatas pada periode waktu tertentu dari 2005 hingga 2018.
\end{abstract}

Kata Kunci: NPL, panel dinamis, pertumbuhan ekonomi, suku bunga kredit, inflasi, pengangguran

\section{ABSTRACT}

This study aims to examine and analyze the impact of macroeconomic variables on Conventional Bank Nonperforming Loans (NPLs) in ASEAN. The method used is the dynamic panel during the period 20052018. Estimation results show that macroeconomic variables such as economic growth, lending rates, inflation and unemployment have a significant effect on Conventional Bank Nonperforming Loans (NPLs) in ASEAN. The limitation in this study is that it does not use the banking indicator variable as a determinant of NPL and is limited to a certain time period from 2005 to 2018.

Keywords: NPL, dynamic panel, economic growth, lending rate, inflation, unemployment

\section{PENDAHULUAN}

Nonperforming Loans (NPLs) penting karena mencerminkan kualitas kredit dari portofolio pinjaman bank, dan secara agregat, mencerminkan kualitas kredit dari portofolio pinjaman sektor perbankan di suatu negara. Pemahaman tentang faktor-faktor yang mempengaruhi tingkat NPL sangat penting untuk fungsi manajemen risiko bank dan untuk stabilitas keuangan (Jameel, 2014).Penentu NPL di suatunegara adalah tema utama dalam literatur 
perbankan. Hal ini karena siklus pinjaman bank dan timbulnya kerugian dari pinjaman perbankan secara abnormal menarik bagi para pembuat kebijakan dalam beberapa tahun terakhir. Pinjaman perbankan yang banyak terjadi gagal bayar, maka akan meningkatkan NPL, rasio NPL yang tinggi akan menyebabkan krisis perbankan secara sistemik (Zhu dkk, 2014). Oleh sebab itu, perbankan di suatu negara atau kawasan harus tetap memperhatikan rasio NPL.

Perbankan di negara ASEAN selalu menjaga rasio NPL agar tidak terlalu tinggi. Jikan NPL mengalami peningkatan di ASEAN, maka akan menjadi beban besar pada posisi keuangan bank (terutama operasi peminjaman bank).Peningkatan NPL akan secara luas mempengaruhi bank, perusahaan dan sektor ritel.Tren NPL yang meningkat di negara ASEAN akan mengakibatkan depresi di pasar keuangan, memperlambat kelayakan kredit peminjam.

Dua alasan untuk kenaikan NPL baru-baru ini, terlihat jelas di seluruh bank di kawasan ASEAN, sehingga menjadi perhatian pembuat kebijakan. Pertama, bank-bank di ASEAN tetap kritis terhadap sistem keuangan. Hal ini karena pengaruh faktor makroekonomi dalam mendorong NPL, dan di sisi lain, penumpukan NPL yang berkelanjutan dapat menghambat fungsi sektor keuangan secara keseluruhan, membebani saluran kredit dan memperlambat ekonomi kegiatan. Kedua, mengingat risiko yang berasal dari integrasi keuangan di kawasan ASEAN, keterkaitan keuangan regional dan global yang lebih dalam dapat memperkuat penyebaran guncangan, sehingga mengancam stabilitas keuangan.

Variabel makroekonomi yang digunakan dalam studi ini untuk mempengaruhi NPL di negara ASEAN yaitu pertumbuhan ekonomi, suku bunga kredit, inflasi, dan pengangguran. Pertumbuhan ekonomimenjadi indikator pendapatan bagi masyarakat dan perusahaan. Peningkatan pertumbuhan ekonomi akan mengakibatkan pendapatan masyarakat dan profit perusahaan, sehingga kemampuan untuk membayar kredit meningkat dan dampaknya NPL menurun (Anjom dan Karim, 2016). Sebaliknya kondisi penurunan pertumbuhan ekonomimenunjukkan pendapatan individu dan profit perusahaan yang menurun, sehingga kemampuan untuk membayar kredit menurun, akibatnya berdampak pada peningkatan rasio NPL. Berdasarkan uraian tersebut, maka pertumbuhan ekonomi berdampak negatif terhadap NPL. 
Suku bunga juga berdampak pada pergerakan NPL. Suku bunga dalam hal ini adalah suku bunga kredit berdasarkan bank konvensional. Peningkatan suku bunga kredit bagi perbankan sangat diminati, karena pendapatan yang bersumber dari kredit tinggi, namun tingginya suku bunga kredit penuh resiko, sebab nasabah akan kesulitan membayar, dan resiko gagal bayar tinggi (Clichici dan Colesnicova, 2014). Kondisi ini akan memperburuk rasio NPL. Semakin tinggi resiko gagal bayar, maka rasio NPL perbankan semakin tinggi, sebaliknya, semakin rendah resiko gagal bayar, maka rasio NPL perbankan semakn rendah. Oleh karena itu peningkatan suku bunga kreditakan berdampak positif terhadap peningkatan rasio NPL.

Inflasi menjadi variabel makroekonomi yang terus diperhatikan oleh pelaku ekonomi. Hal ini karena inflasi yang tidak stabil akan memperburuk kinerja ekonomi suatu negara, sehingga juga berdampak pada kinerja perbankan. Inflasi menjadi indikator daya beli. Inflasi yang tinggi memberikan arti bahwa daya beli masyarakat menurun (Hanifan dan Umanto, 2017). Hal ini karena pendapatan yang diperoleh secara riil juga menurun. Kondisi ini akan mempengaruhi profit perusahaan, sebab masyarakat mengurangi konsumsi. Oleh karena itu pendapatan riil masyarakat dan profit perusahaan menurun, maka meningkatkan risiko gagal bayar juga tinggi, sehingga NPL meningkat. Semakin tinggi inflasi, maka NPL semakin meningkat, semakin rendah inflasi, maka NPL akan semakin menurun. Oleh karena itu, inflasi berdampak positif terhadap NPL.

Pengangguran juga menjadi variabel yang dapat mempengaruhi NPL. Peningkatan pengangguran akan berdampak negatif terhadap aliran arus kas rumah tangga dan meningkatkan beban utang.Sehubungan dengan perusahaan, peningkatan pengangguran dapat menandakan penurunan produksi sebagai akibat dari penurunan permintaan yang efektif (Saba dkk, 2012).Hal ini dapat menyebabkan penurunan pendapatan dan kondisi utang yang rapuh. Pengangguran yang meningkat akan mendorong resiko gagal bayar lebih tinggi. Oleh karena itu, peningkatan pengangguran akan menyebabkan peningkatan NPL, sebaliknya penurunan pengangguran akan menyebabkan penurunan NPL.

Studi tentang dampak variabel makroekonomi terhadap NPL telah banyak diuji secara empiris. Ginting (2016) melakukan penelitian tersebut. Studi Ginting (2016) bertujuan untuk mengetahui perkembangan kredit dan kredit macet (NPL) perbankan di Indonesia dan mengetahui pengaruh variabel makroekonomi terhadap NPL perbankan di Indonesia. Studi ini menggunakan metode kualitatif dan kuantitatif. Pendekatan kuantitatif 
menggunakan metode dynamic panel data yang menggunakan data dari tahun 2006-2014. Hasil studi ini menunjukkan bahwa perkembangan kredit dalam periode tersebut mengalami tren meningkat, peningkatan kredit yang disalurkan oleh perbankan diikuti oleh peningkatan NPL perbankan. Studi ini juga menemukan bahwa ternyata kondisi makroekonomi, terutama GDP, memiliki pengaruh yang negatif terhadap NPL. Artinya jika semakin membaiknya perekonomian yang ditandai dengan semakin meningkatnya pertumbuhan ekonomi akan semakin mengurangi NPL dan memiliki pengaruh yang positif dengan variabel tingkat suku bunga pinjaman serta inflasi. Berdasarkan temuan tersebut maka diperlukan sinergitas antara pemerintah sebagai otoritas fiskal dengan Bank Indonesia untuk menciptakan kondisi makroekonomi yang baik yang dapat mengurangi kredit macet perbankan di Indonesia.

Lee dan Rosenkranz (2009) melakukan penelitian determinan NPL di Asia. Tujuan penelitian Lee dan Rosenkranz (2009) yaitu menguji dan menganalisis dampak variabel makroekonomi terhadap NPL di Asia. Metode yang digunakan yaitu panel VAR selama periode 1995-2014. Hasil estimasi menunjukkan bahwa variabel makroekonomi memiliki efek umpan balik terhadap NPL. Fungsi impuls respon menunjukkan bahwa rasio NPL yang meningkat yang diakibatkan karena penurunan pertumbuhan pertumbuhan ekonomi dan meningkatkan tingkat pengangguran.

Soh (2019) melakukan penelitian tentang faktor yang mempengaruhi NPL di AsiaPasific. Tujuan penelitian Soh (2019) yaitu menguji dan menganalisis dampak variabel makroekonomi terhadap NPL di Asia-Pasific tahun 2010-2016. Metode yang digunakan yaitu regresi data panel. Hasil estimasi menunjukkan bahwa pertumbuhan ekonomi, inflasi, suku bunga, dan pengangguran berpengaruh signifikan terhadap NPL.

Research gap dalam studi ini yaitu sampel penelitian yang berbeda dan periode yang lebih baru. Diharapkan research gap tersebut memberikan kontribusi pada naska akademik. Studi ini terdiri dari tiga poin, yaitu pendahuluan, metode penelitian, hasil dan pembahasan, serta simpulan. Poin pertama menjelaskan NPL di ASEAN dan secara teori bagaimana variabel makroekonomi berdampak pada NPL. Poin kedua yaitu menjelaskan prosedur pengolahan atau teknik analisis, model analisis, sertajenis dan sumber data. Poin ketiga yaitu menjelaskan hasil estimasi dari panel dinamis. Poin keempat yaitu menguraikan simpulan dan memberikan rekomendasi kebijakan. 


\section{METODE PENELITIAN}

Penelitian ini menggunakan jenis data sekunder dari tahun 2005-2018. Jenis data sekunder yaitu data yang diperoleh dari suatu institusi baik institusi domestik maupun internasional, artinya data tersebut sudah disediakan pada website institusi tersebut, sehingga peneliti tidak perlu melakukan survey data. Sampel penelitian yaitu ASEAN (Brunei Darusalam, Indonesia, Kamboja, Filipina, Malaysia, Singapura, Thailand, dan Vietnam), sedangkan Myanmar dan Laos tidak ikut sertakan karena data yang dibutuhkan tidak tersedia. Secara ekonometrika data dalam studi nii tergolong kedalam jenis data panel, karena gabungan dari data cross section dan time series. Periode 2005-2018 digunakan karena pada periode tersebut negara-nagara yang disebutkan sudah bergabung dan selama periode tersebut terdapat peningkatan NPL di ASEAN. Sumber data yang digunakan dalam penelitian ini diperoleh dari website Bank Dunia. Data tersebut diambil dari menu World Indicator Development. Metode yang digunakan yaitu GMM (Generalized Moment Method).

Studi ini menggunakan model panel dinamis. Berikut ini model empiris yang digunakan dalam studi ini:

$$
\begin{aligned}
& N P L_{i t}=\alpha+\beta_{1} N P L_{i t-1}+\beta_{2} P E_{i t}+\varepsilon_{1 i t} \\
& N P L_{i t}=\alpha+\beta_{1} N P L_{i t-1}+\beta_{2} P E_{i t}+\beta_{3} I N F_{i t}+\varepsilon_{2 i t} \\
& N P L_{i t}=\alpha+\beta_{1} N P L_{i t-1}+\beta_{2} P E_{i t}+\beta_{3} I N F_{i t}+\beta_{4} L R_{i t}+\varepsilon_{3 i t} \\
& N P L_{i t}=\alpha+\beta_{1} N P L_{i t-1}+\beta_{2} P E_{i t}+\beta_{3} I N F_{i t}+\beta_{4} L R_{i t}+\beta_{5} U N_{i t}+\varepsilon_{i t}
\end{aligned}
$$

dimana NPL, PE, INF, LR, dan UN adalah Nonperforming Loans (NPLs), pertumbuhan ekonomi, inflasi, suku bunga kredit, dan tingkat pengangguran. $N P L_{i t-1}$ merupakan lag dari variabel dependen. Satuan semua variabel berupa persen. Koefisien $\beta_{2}<0$, artinya pertumbuhan ekononi berdampak negatif terhadap NPL, sedangkan koefisien $\beta_{3} . . \beta_{5}>0$, artinya inflasi, suku bunga kredit, dan tingkat penganggurang berdampak positif terhadap NPL. $\varepsilon_{i t}$ menunjukkan error term model.

Metode estimasi GMM Arellano-Bond menghasilkan estimasi tidak bias, konsisten dan efisien. Generalized Method of Moment (GMM) merupakan metode penaksiran parameter perluasan dari metode momen. Metode momen tidak dapat digunakan apabila banyaknya variabel instrumen lebih besar dibandingkan dengan jumlah parameter yang 
akan ditaksir. GMM menyamakan momen kondisi dari populasi dengan momen kondisi dari sampel. Metode GMM merupakan salah satu metode yang dapat mengatasi kondisi data dengan pelanggaran asumsi-asumsi pada analisis regresi. GMM didapat dengan cara meminimumkan jumlah kuadrat terboboti dari momen kondisi sampel. Estimasi GMM disebut juga dengan regresi panel dinamis.

Regresi data panel dinamis merupakan metode regresi yang menambahkan lag variabel dependen untuk dijadikan sebagai variabel independen (Baltagi, 2005) Model data panel dinamis digunakan untuk menggambarkan hubungan antara variabel-variabel ekonomi yang pada kenyataannya banyak yang bersifat dinamis. Hubungan variabelvariabel ekonomi pada dasarnya merupakan suatu kedinamisan yakni variabel tidak hanya dipengaruhi variabel pada waktu yang sama tetapi juga dipengaruhi variabel pada waktu yang sebelumnya. Model panel dinamis ini dapat dilihat dari keberadaan lag variabel terikat diantara variabel- variabel regressor. Oleh karena itu, model data panel dinamis lebih sesuai digunakan dalam analisis perekonomian. Relasi di antara variabel-variabel ekonomi pada kenyataannya banyak yang bersifat dinamis. Analisis data panel dapat digunakan pada model yang bersifat dinamis dalam kaitannya dengan analisis penyesuaian dinamis (dynamic of adjustment). Hubungan dinamis ini dicirikan oleh keberadaan lag variabel dependen di antara variabel-variabel regresor.

Pendekatan GMM merupakan salah satu yang populer. Setidaknya ada dua alasan yang mendasari, pertama, GMM merupakan common estimator dan memberikan kerangka yang lebih bermanfaat untuk perbandingan dan penilaian. Kedua, GMM memberikan alternatif yang sederhana terhadap estimator lainnya, terutama terhadap maximum likelihood. Penduga GMM juga tidak terlepas dari kelemahan. Adapun beberapa kelemahan metode ini, yaitu: (i) GMM estimator adalah asymptotically efficient dalam ukuran contoh besar tetapi kurang efisien dalam ukuran contoh yang terbatas (finite); dan (ii) estimator ini terkadang memerlukan sejumlah implementasi pemrograman sehingga dibutuhkan suatu perangkat lunak (software) yang mendukung aplikasi pendekatan GMM.

Arellano dan Bond mengusulkan pendekatan method of moment atau biasa disebut dengan Generalized method of moments (GMM). Pemilihan model GMM terbaik menggunakan beberapa kriteria. Pertama, instrumen valid, jika uji Sargan menunjukan penolakan hipotesis nol. Apabila hasil metode FD-GMM menunjukan instrumen yang digunakan tidak valid, maka digunakan metode SYS-GMM. Uji Sargan digunakan untuk 
overidentifiying restriction untuk menguji masalah validitas pada instrumen yang digunakan. Jika instrumen valid maka tidak ada korelasi antara instrumen dengan komponen error. Kedua, konsisten, jika pada uji Arellano-Bond statistik AR(1) menunjukan hipotesis nol ditolak dan AR (2) menunjukan hipotesis tidak tolak hipotesis nol. Uji Arellano-Bond merupakan uji autokorelasi pada pendekatan GMM untuk mengetahui konsistensi estimasi. Berdasarkan ketiga kriteria tersebut maka didapat model GMM terbaik dimana model yang digunakan tersebut tidak bias, estimator yang diperoleh dari model tersebut konsisten, dan instrumen yang digunakan dalam model telah valid.

Hasil estimasi FD-GMM akan dilihat apakah instrumen yang digunakan valid. Jika tidak memenuhi, maka akan dilanjutkan dengan menggunakan pendekatan SYS-GMM untuk mengatasi masalah validitas instrumen pada pendekatan FD-GMM. Pengujian validitas instrument pada pendekatan FD-GMM, dapat digunakan uji Sargan. Uji Sargan untuk overidentifying restriction merupakan suatu pendekatan untuk mendeteksi masalah validitas instrumen. Hipotesis nol untuk uji ini menyatakan bahwa tidak ada masalah dengan validitas instrumen (instrumen valid) dengan artian bahwa instrumen tersebut tidak berkorelasi dengan error pada persamaan FD-GMM. Dalam uji ini terdapat nilai probabilitas chi-square, dimana jika nilai probabilitasnya di bawah tingkat signifikasi $1 \%, 5 \%$ atau $10 \%$ maka dikatakan model tidak valid atau hipotesis nol (Ho) ditolak. Jika nilai probabilitasnya di atas tingkat signifikasi $1 \%, 5 \%$ atau $10 \%$ maka dikatakan model valid atau hipotesis nol (Ho) diterima.

Uji autokorelasi dengan menggunakan statistik Arellano-Bond. Dalam uji ini terdapat nilai probabilitas $\mathrm{z}$, dimana jika nilai probabilitasnya di bawah tingkat signifikasi $1 \%$, 5\% atau $10 \%$ maka H0 ditolak, yang menunjukkan adanya autokorelasi di dalam model sehingga tidak valid. Sebaliknya, jika nilai probabilitasnya di atas tingkat signifikasi $1 \%, 5 \%$ atau $10 \%$ maka $\mathrm{H} 0$ ditolak,yang menunjukkan tidak adanya autokorelasi di dalam model sehingga valid. Menduga parameter model data panel dinamis akan digunakan terlebih dahulu metode first difference generalized method of moments (FD-GMM). Selanjutnya dari hasil yang diperoleh juga akan diuji tingkat signifikansi serta tanda dari setiap koefisien estimasi yang diperoleh. Tanda koefisien ini akan dianalisis untuk melihat relevansinya dengan teori. Kemudian dari hasil estimasi juga akan dilakukan analisis untuk menjawab tujuan dan hipotesis penelitian. 


\section{HASIL ESTIMASI DAN PEMBAHASAN}

Hasil estimasi dan pembahasan menjadi poin penting dalam suatu penelitian. Hal ini karena berkaitan dengan kecocokan antara hasil uji secara empiris dengan teori yang digunakan. Selain itu hasil estimasi yang telah diolah sesuai dengan studi terdahulu atau tidak, maksudnya didukung dengan studi terdahulu atau tidak. Berikut ini hasil estimasi panel dinamis:

\section{Tabel 1}

Hasil Estimasi Panel Dinamis dengan Variabel Dependen NPL

\begin{tabular}{|l|c|c|c|c|}
\hline Variabel & Model 1 & Model 2 & Model 3 & Model 4 \\
\hline NPLit-1 & $1,069 * * *$ & $0,862^{* *}$ & $0,083^{* *}$ & $0,876^{* * *}$ \\
& $(0,081)$ & $(0,339)$ & $(0,371)$ & $(0,049)$ \\
\hline PE & $-0,219 *$ & $-0,259^{* * *}$ & $-0,235^{*}$ & $-0,066^{* * *}$ \\
& $(0,124)$ & $(0,103)$ & $(0,119)$ & $(0,023)$ \\
\hline LR & - & $0,093^{* * *}$ & 0,150 & 0,034 \\
& & $(0,014)$ & $(0,208)$ & $(0,033)$ \\
\hline INF & - & - & $0,108^{*}$ & $-0,008$ \\
& & & $(0,063)$ & $(0,053)$ \\
\hline UN & - & - & - & $0,083 * * *$ \\
& & & & $(0,021)$ \\
\hline AR(1) & 0,181 & 0,256 & 0,155 & 0,178 \\
\hline AR(2) & 0,211 & 0,807 & 0,254 & 0,889 \\
\hline Sargan Test & 0,519 & 0,201 & 0,338 & 0,434 \\
\hline Hansen Test & 0,586 & 0,402 & 0,415 & 0,999 \\
\hline
\end{tabular}

Keterangan: $* * *, * * *$ signifikan pada $10 \%, 5 \%$, dan $1 \%$

dimana NPL, PE, INF, LR, dan UN adalah Nonperforming Loans (NPLs), pertumbuhan ekonomi, inflasi, suku bunga kredit, dan tingkat pengangguran.

Tabel 1 menunjukkan hasil semua model valid digunakan, karena probabilitas Sargan test lebih dari tingkat signifikansi, sehingga model GMM dapat digunakan. Hansen test juga menunjukkan bahwa semua model juga terbebas dari heteroskedastisitas karena probabilitas lebih dari tingkat signifikansi. AR(1) dan AR(2) menunjukkan uji 
autokorelasi. Berdasarkan pada hasil tersebut, maka terbebas dari autokorelasi, karena probabilitas $\mathrm{AR}(1)$ dan $\mathrm{AR}(2)$ lebih dari tingkat signifikansi 1\%, 5\%, dan $10 \%$.

Model 1 menunjukkan bahwa pertumbuhan ekonomi berpengaruh signifikan terhadap NPL. Model 2 menunjukkan bahwa pertumbuhan ekonomi dan suku bunga kredit berpengaruh signifikan terhadap NPL. Model 3 menunjukkan bahwa pertumbuhan ekonomi dan inflasi berpengaruh signifikan terhadap NPL, sedangkan suku bunga kredit tidak berpengaruh signifikan terhadap NPL. Model 4 menunjukkan bahwa pertumbuhan ekonomi dan pengangguran berpengaruh signifikan terhadap NPL, sedangkan suku bunga kredit dan inflasi tidak berpengaruh signifikan terhadap NPL.

Hasil estimasi pertumbuhan ekonomi menunjukkan bahwa pertumbuhan ekonomi berpengaruh signifikan negatif terhadap NPL. Hal ini memberikan arti bahwa peningkatan pertumbuhan ekonomi di negara ASEAN dapat menurunkan rasio NPL negara ASEAN. Pertumbuhan ekonomi di negara ASEAN yang semakin tinggi akan meningkatkan pendapatan masyarakat dan profit perusahaan swasta di negara-negara ASEAN, sebab pendapatan masyarakat yang semakin tinggi, maka akan merasa kaya, sehingga pembayaran tagihan kredit pada perbankan lancar, akhirnya rasio NPL turun, begitu juga untuk perusahaan swasta. Pertumbuhan ekonomi semakin tinggi menandakan bahwa perusahaan-perusahaan swasta di negara-negara ASEAN produktif sehingga profit yang diperoleh perusahaan tinggi, akhirnya perusahaan dapat membayar jatuh tempo kredit pada perbankan.

Hasil estimasi menunjukkan bahwa suku bunga kredit berpengaruh signifikan positif terhadap NPL. Hal ini memberikan arti bahwa peningkatan suku bunga kredit di negara ASEAN dapat meningkatkan rasio NPL negara ASEAN. Suku bunga kredit di negara ASEAN yang semakin tinggi akan meningkatkan risiko gagal bayar pada perbankan. Kondisi ini memberikan arti bahwa unit defisit yang meminjam pada perbankan tidak memiliki kemampuan untuk membayar pinjaman yang sudah dilakukan. Semakin tinggi tingkat suku bunga kredit, maka cicilan yang akan dibayar juga akan semakin tinggi. Hal ini akan meningkatkan NPL di negara-negara ASEAN.

Hasil estimasi menunjukkan bahwa inflasi berpengaruh signifikan positif terhadap NPL di negara ASEAN. Hasil tersebut menunjukkan bahwa peningkatan inflasi di negara ASEAN akan mendorong NPL di ASEAN juga tinggi. Peningkatan inflasi diakibatkan oleh peningkatan harga barang secara umum dan kebijakan yang bersifat administrasi. 
Faktor lain yaitu seperti kondisi ekonomi domestik yang tidak stabil, dan pasar valas yang semakin tertekan. Inflasi yang tinggi akan menyebabkan daya beli masyarakat menurun, sebab pendapatan yang diperoleh secara riil akan berkurang, sehingga masyarakat merasa tidak kaya lagi. Hal ini akan menyebabkan kredit macet, sehingga rasio NPL di negara ASEAN tinggi dan resiko gagal bayar tinggi. Sisi perusahaan, jika masyarakat mengurangi konsumsi, maka produksi industri akan semakin dikurangi, hal ini akan menyebabkan penurunan laba, sehingga perusahaan-perusahaan di negara ASEAN tidak dapat membayar kredit yang sudah jatuh tempo. Hal ini akan menyebabkan NPL tinggi.

Hasil estimasi variabel pengangguran menunjukkan bahwa secara signifikan positif mempengaruh NPL di negara ASEAN. Peningkatan pengangguran di negara-negara ASEAN akan meningkatkan rasio NPL. Pengangguran menjadi masalah makroekonomi yang cukup memprihatinkan bagi para pembuat kebijakan di negara-negara ASEAN. Pengangguran yang belum teratasi akan menimbulkan masalah ketidakstabilan ekonomi. Pengangguran mengakibatkan produktivitas negara-negara ASEAN menurun, sehingga tingkat pertumbuhan ekonomi mengalami penurunan dan kesejahteraan masyarakat juga menurun. Jika kondisi tersebut berkelanjutan, maka membuat rasio NPL tinggi. Semakin tidak sejahtera masyarakat ASEAN dan semakin tidak produktif industri-industri di negara ASEAN, maka risiko gagal bayar semakin tinggi, sehingga NPL di negara ASEAN tinggi.

\section{PENUTUP}

Berdasarkan hasil estimasi maka semua model valid digunakan, karena probabilitas Sargan test lebih dari tingkat signifikansi, sehingga model GMM dapat digunakan. Hansen test juga menunjukkan bahwa semua model juga terbebas dari heteroskedastisitas karena probabilitas lebih dari tingkat signifikansi. Hasil uji autokorelasi juga menunjukkan terbebas dari autokorelasi sebab probabilitas $\operatorname{AR}(1)$ dan $\operatorname{AR}(2)$ lebih dari tingkat signifikansi 1\%, 5\%, dan 10\%. Hasil estimasi menunjukkan bahwa pertumbuhan ekonomi, suku bunga kredit, inflasi, dan tingkat pengangguran berpengaruh signifikan terhadap NPL di negara ASEAN. 


\section{DAFTAR PUSTAKA}

Anjom, W., \&Karim, A.M. (2016). Relationship between non-performing loans and macroeconomic factors (with specific factors: a case study on loan portfolios- SAARC countries prespective). Asia Pacific Journals of Finance and Risk Management, 15(3), 84-103

Baltagi, BH.(2005).Econometric Analysis of Panel Data, Ed.3, John Wiley \& Sons, Ltd, England.

Clichici, D., Colesnicova, T. (2014). The impact of macroeconomic factors on nonperforming loans in the Republic of Moldova. Journal of Financial and Monetary Economics, Centre of Financial and Monetary Research "Victor Slavescu", 1(1), 7378

Ginting, Ari Mulianta. (2016). Pengaruh Makroekonomi Terhadap Non Performing Loan (NPL) Perbankan. Jurnal Ekonomi \& Kebijakan Publik, 7(2), 159 - 170

Hanifan, F. \& Umanto. (2017). The impact of macroeconomic and bank-specific factors toward non-performing loan: evidence from Indonesian public banks. Banks and Bank Systems, 12(1), 67-74

Jameel, K. (2014). Crucial Factors of Nonperforming loans Evidence from Pakistani Banking Sector. International Journal of Scientific \& Engineering Research, 5(7), 704-710

Lee, Junkyu, \&Rosenkranz, Peter. (2019). Nonperforming Loans in Asia: Determinants and Macrofinancial Linkages. ADB Economics Working Paper.

Saba, I., et al. (2012). Determinants of Non Performing Loans: Case of US Banking Sector. The Romanian Economic Journal, XV(44), 141-152.

Soh, Weini. (2019). Non-Performing Loan and Economic Determinants in Asia-Pacific Countries: Evidence from Credit Card Debt. International Journal of Recent Technology and Engineering (IJRTE), 7(6S5), 1609-1614

Zhu, N., et al. (2014). Productivity, efficiency, and non-performing loans in the Chinese banking industry. Social Science Journal, 52(4), 468-480 